\title{
PAKISTAN'S MAGNITUDE FOR CHINA: A NARRATIVE OF GEO-STRATEGIC BARGAIN
}

Muhammad Hassan*

Muhammad Rizwan ${ }^{+}$

Pasand Ali Khoso

\section{Abstract}

This paper attempts to analyse the geo-strategic magnitude of Pakistan for China. Including other factors, the geographical position of Pakistan plays an important role in the formulation of their mutual ties. Sino-Indian conflict further enhanced Pak-China relationship mainly reflecting their reciprocal interests. In addition to geo-political ties, economic benefits attracted Chinese attention to maintain a friendly relationship with Pakistan by signing bilateral trade agreement during early 1960s. Similarly, Pakistan provided a naval base to China, which decreased the influence of USA and India in the Arabian Sea, Indian Ocean and Central Asian States. However, due to the world third deepest seaport (Gwadar Port), Pakistan became more valuable to China. Moreover, launching of China- Pakistan Economic Corridor (CPEC) in 2014 has greatly enhanced the geographical importance of Pakistan for the whole region including China. The scope of present study provides a realization to the fact that significance of Pakistan for Chinese interest is beyond the common thinking. This article tries to pin point the current scenario with increasing significance of Pakistan for China.

Keywords: Strategic location, Gwadar, Interest-based Relationship, Warm waters

"Senior Research Fellow National Institute of Historical and Cultural Research, Quaid-i-Azam University. Email: mhassan@qau.edu.pk (Corresponding author)

+Associate Professor, Department of Pakistan Studies, Abbottabad University of Science \&Technology. Email: drmuhammadrizwanhu@yahoo.com $\ddagger$ Assistant Professor, Department of Sociology, University of Sindh. Email: pasand.ali@usidh.edu.pk 


\section{INTRODUCTION}

The journey of Pakistan-China friendship started during early 1950s when Pakistan, the first Muslim state, recognized the Communist China and established diplomatic relations (Rizvi, 1993). Both countries share a border of approximately 500km (Durrani, 2017). Soon after establishment of the diplomatic ties, Pakistan accorded Chinese recognition, co-sponsored a resolution in the United Nations Organization General Assembly, and supported Chinese stance in the world organization (Shahi, 2015). Probably, strategic and political considerations contributed much in the development of relationship between the two than any other factor.

Similarly, when China entered the Korean War to ensure its sanctuary, Pakistan, in spite of huge pressure, refused to brand China as an aggressor on the platforms of United Nations. In return, the Chinese leadership appreciated Pakistan's stand (Ali, 2001). China, unlike the Soviet Union, understood that Pakistan's rationale for joining Southeast Asian Treaty Organisation (SEATO) was to strengthen its own security. At the Bundung Conference in 1955, the Chinese Premier Zhou Enlai publicly acknowledged Pakistani leadership's assurance on defence agreements with the West (Ali, 2001).

Moreover, the Sino-Indian border conflict during early 1960s proved a major junction-point in Pak-China relationship where Pakistan fully supported Chinese stance (Cohen, 2012). Pakistan, unlike many other countries of the world, not only condemned the aggressive move by the Indian forces but also indicated its support to the Chinese cause. However, as per expectations, both United States and Britain showed their sympathies towards Indian stance and provided every possible assistance against China. This situation opened a new chapter in India-USA relationship but at the same time, it proved a major cause to bring Pakistan closer to China. 
In order to make a long lasting relationship, both Pakistan and China signed the boundary agreement, due to which Pakistan gained 750sq miles territory monitoring scraping lands and salt mines, which had been under the control of the China government (Ali, 2001). Similarly, both countries had signed three more agreements i.e., first trade agreement, first cultural agreement, and air agreement (Shahi, 2015). Both economic and military support to Pakistan enhanced the mutual ties between China and Pakistan. During Indo-Pakistan war in 1965 and after the separation of East Pakistan in 1971, China fully supported Pakistan politically and military. China denounced the Indian aggression and supported the just struggle of the people of Pakistan to defend their sovereignty and territorial integrity (Ali, 2001). With the Chinese assistance, Pakistan has also developed a small fleet of nuclear reactors (Ebinger, 2011, p. 62). China provided weapon design technology, reactors and transferred missile technology to Pakistan for peaceful purposes (Jetly, 2009, p. 232).

Present study is an attempt to analyse the assumption that the deeprooted relationship between China and Pakistan is mainly depending on the level of magnitude realized for each other. With an objective to investigate the factors mainly responsible to enhance the importance of Pakistan for China, the study addresses following research questions:

- What is the nature of relationship between China and Pakistan?

- How the revival of Silk Route is providing a shortest passage to the Chinese authority to access the Warm Waters of India Occasion.

- What are the main factors for China that ultimately shifted the paradigm from India to Pakistan?

- Why the importance of Pakistan for China is on constant increase during the last few years? 


\section{RESEARCH METHOD}

The present study employs a qualitative research approach to analyse the data taken from primary as well as secondary sources including official documents, statements, speeches, books, journals and newspapers. Critical analysis approach has been used to answer the research questions. It has been tried to answer the question that how with high level of trust, both countries developed a multi-level cooperation, especially, in the field of politics and security.

\section{ANALYSIS AND DISCUSSION}

\section{Aspects of Pakistan-China relations}

The diplomatic relations between China and Pakistan were formally established in early 1950s. Although Pakistan's inclusion in SEATO and Central Treaty Organisation (CENTO) created an environment of mistrust between the two countries but meeting between the Chinese Premier Chou En Lai and Pakistani Prime Minister Muhammad Ali Bogra in Bandug conference paved the way for future relationship. Two more incidents, in the meantime, including the Ayub Khan's support to China during his visit to the US in early 1960s and the settlement of border dispute brought China closer to Pakistan. However, the Sino-India war of 1962 shifted the whole paradigm towards Pakistan. With the passage of time, these relations boosted up to a high level, the people of both sides have developed feelings for each other. China has emerged as true friend of Pakistan and provided every possible assistance to Pakistan during every critical time including 1965 and 1971 Indo-Pakistan wars.

However, the separation of Eastern wing was the most critical time in the political history of Pakistan when it needed every kind of support. Chinese leadership, at this occasion, did not recognize Bangladesh and considered India as an aggressor. It was the period, in which both the states started to support each other's stances on the issues of Taiwan and Kashmir. During the 1971 war, China extended its 
diplomatic support to Pakistan; however, unlike Pakistan-India war of 1965, Chinese authorities refrained from taking a military posture against India due to possible USSR attack on Chinese Nuclear installations. USSR, who had signed a treaty of friendship, peace and cooperation with India in August 1971, was no more a neutral country as the agreement provided for mutual help to the parties in case of war. China, in spite of threats, provided a strong moral and political support to Pakistan and condemned the Indian aggression. Very soon, Pakistan reciprocated Chinese help by playing an intermediary role to bring China and USA closer to each other. A secret mission of Henry Kissinger's visit to China via Pakistan paved the way for President Nixon visit to China.

In year 1972, Pakistan extended its recognition to North Korea and North Vietnam, which pleased Chinese authorities, who in return, assured Pakistan for every possible help after the Indian atomic explosion in July 1974. A series of official visits from both sides helped to boost the mutual ties. Chinese vice-premier visited Pakistan on $20^{\text {th }}$ April 1975. This six days official visit enhanced the level of mutual understanding between China and Pakistan. In May 1976, Prime Minister Zulfiqar Ali Bhutto visited China. This visit was very meaningful as Chinese had acquired a new political leadership after Chou En Lai's death. At the end of the visit a joint communiqué was issued, which reaffirmed Chinese support on Kashmir issue. Pakistan vigorously supported China's admission to the United Nations. These efforts were rewarded when China became a full-fledged member of the United Nations on October 25, 1976.

In December, 1979, when the Soviet Union Russia invaded Afghanistan and Pakistan become a front line state, China, in spite of having reservations at the role of USA in the region, fully supported Pakistan and demanded the withdrawal of the USSR forces from Afghanistan. In addition to this, in 1980's several cultural and trade delegations were exchanged, which contributed expansion in the trade between the two countries. In May 1981, both China and 
Pakistan celebrated 30 years of their friendship and Chinese Prime Minister visited Pakistan in order to show the solidarity. Prime Minister of Pakistan Muhammad Khan Junejo visited China in November 1985 when Chinese authorities extended an interest free loan amounting to US \$ 27 million. In the meantime, Pakistan signed National Machinery and Equipment Import and Export Cooperation for setting up Heavy Electric Complex in Pakistan. China helped Pakistan for modernization of the Heavy Mechanical Complex at Taxila. The process of Chinese cooperation with Pakistan continued and a protocol was signed in May 1987.

After the end of military regime of Zia-ul-Haq, both Nawaz Sharif and Benazir Bhutto followed the policies of friendship and cooperation with China. In this period, Pakistan trusted relationship with China touched over high peaks of mutual friendship and cooperation. Both countries entered into a relationship based upon even closer proximity of perceptions. During the critical time of Kargil Conflict, China once again stood by Pakistan against the vigorous campaign of Indian authorities (Cheema, 2015). However, the most crucial issue was the Chinese supply of M-11 Missiles to Pakistan. In spite of severe criticism from the India, Chinese assistance continued to enable Pakistan to accelerate its indigenous programme to develop Hatf and Shaheen missiles.

China, being the one of the largest exporters and importers, provided possible financial assistance to Pakistan whenever needed. In return, Pakistan decided to provide access to China in yarn, mineral, fruits/vegetables and sports products etc. Pakistan was provided with easy access in Chinese's developed industries including chemicals, fishery, rubber, and engineering equipment etc. Pakistan had not only signed free trade agreement with China in 1963 but also is second major trade partner of Pakistan (Riaz, 2014). Economic and Trade ties between the two countries are based on mutual interest and increasing at a constant level. However, with the provision of shortest way to deep seaport through Korakorum Highway $(\mathrm{KKH})$, both 
countries will get a massive increase in their economic growth.

The Free Trade Agreement of both China and Pakistan during 2006 was executed in two phases, according to which China was to provide financial aid to Pakistan for the construction of Gwadar seaport and it is estimated that the first trade agreement will reach in US \$15 billion during second stage (Hussain, 2017). However, the most important project of Pak-China cooperation in the current scenario is China-Pakistan Economic Corridor. The mega project contains a huge investment of about US $\$ 47$ billion, which was to improve the livings of more than three billion people. This, 3,218 kilometres long route is a combination of roads, rail tacks, and pipelines, by providing an approximately 16,400 MW of energy altogether. However, it will provide shortest energy route from Middle East through Gwadar to China, cutting the existing $12,000 \mathrm{~km}$ voyage to $2,395 \mathrm{~km}$.

\section{Economic aspect}

The geographical position Gwadar enables the country to occupy a significant place in the world of trade and economics. However, in the present-day scenario, the importance of Gwadar port has immensely increased Pakistan's significance for China. As this port provides China a link to the entire world through warm waters, it has become the most marketable project of both countries (Shelton, 2014).

The Gwadar Port is located at the top of Arabian Sea around $75 \mathrm{~km}$ east of Pakistan-Iran border. It is situated at about $460 \mathrm{~km}$ from the west of Qasim port and $400 \mathrm{~km}$ from the Strait of Hurmuz in the east of Chabahar port of Iran. Its importance immensely increased when in 2002 the then President Pervez Musharraf signed an accord with Chinese authorities to build a modern port. China pledged to provide all estimated cost of about US \$ 46 billion as financial assistance to Pakistan to materialize the mega project. As an alternate route of central Asian states to the 'warm waters' once again enhanced the importance of Pakistan (Masood, 2016). The port is strategically situated among three progressively significant areas of the world, 
first the Oil-rich Middle Eastern states, second the high population areas of south Asia and third is the economically emerging with rich recourses Central Asian Republics (CARs). Similarly, Gwadar is close to the access of Gulf region, Middle East and China's largest source of crude and pipeline to western area. By adopting this route, the Chinese would be able to reduce the distance and time needed to transport the fuel while cutting out the blocked sea routes around Singapore. The other possible advantages for China, by adopting the said route, are summarized as:

- Through this project, China can control the entire region including India. It needs to receive a position of a major contributor in the development of a new type of the world order, which could hardly be achieved without having control over the Indian Ocean. Likewise, China also discourages the hegemonic design of India and its policies to welcome other superpowers in the region to challenge Chinese supremacy.

- China has a clear interest in checking the transportation route for its energy shipment from the Persian Gulf. With the assistance of Pakistani route, it can develop the Xinxiang province, which is otherwise not possible.

- Gwadar seaport can be a very promising selection for the oil supply to China. The current block point of oil trade at Hormel is becoming stopped around 80 per cent of the oil deliver through the Strait of Malacca. Similarly, the Strait of Malacca jammed through the United States so Gwadar can help another route for China trade. Hence, Gwadar, on the front of strait of Houmuz, provides China to Strait of Malacca.

- In order to reduce the economic gap and to stop global migration from east to west, through 'Go West' policy, China needs Gwadar port. To market goods Gwadar Sea port provides an approach to a port at $1500 \mathrm{~km}$. Similarly, the Xinjiang region lies $4500 \mathrm{~km}$ from east China beach but $2500 \mathrm{~km}$ from Gwadar deep seaport. In this 
way, Chinese ships will cover not more than $10000 \mathrm{~km}$ through Strait of Malacca, the most feasible to attain the objective (Naseem, 2014).

In fact, Gwadar seaport is beneficial for both Pakistan and China largely. For China, it is the shortest trade route to Xinxiang province to Arabian Sea. Chinese economy is developing with the ratio of almost 9 percent each year with trade level of US \$1.76 trillion and GNP extending up to 7.3 percent resulting its foreign trade assets of US \$ 601 billion (Naseem, 2014). It not only enables China to increase its oil-import area but also provides a main supplying point (Naseem, 2014).

\section{Geographical aspect}

Azad Kashmir, mainly the areas of Gilgit Baltistan, shares its about $500 \mathrm{~km}$ borders with China. This area is a landlocked region surrounded by Pakistan, India, Afghanistan and China (Bukhari, 2014). Its geographical location, in current scenario where America is controlling Afghan administration, India is struggling hegemonic control and China is striving for economic uplift through CPEC, provides a unique significance (Fayaz, 2016). Due to the geographical location and geo-strategic and economic importance, all the three countries incorporated the area of Kashmir with themselves. Due to its geo-strategical significance, China is also taking deep interest in every development of Kashmir and started many projects, particularly, in the areas of Pakistani held Kashmir. Gilgit Baltistan, the north-western region, is providing easy access to China to other parts of Pakistan and finally to the entire world.

With the population of almost 4.6 million Gilgit Baltistan has strategic importance for China. It directly provides China a military potential against India because the area connected with Indian Occupied Kashmir (IOK), China has minimum border shared with its enemy therefore it make a string of the pearl strategy. There are three core interests of China in the valley of Kashmir: 
- The western part of Kashmir is a trade corridor, which provides a link between Xinxiang and Gwadar port and Gwadar with CARs. While the eastern part of Kashmir cannot link with $\mathrm{KKH}$ and Gwadar port, because it has mostly on the large distance and under the control of India.

- The second interest of China in the western Kashmir is, it provide access to Afghanistan and Iran. China has border with Afghanistan but it cannot provide easy route due to the large mountains, underdeveloped and large distance with Kabul.

- China seems interested in enhancing its influence beyond its borders. In the south of China India is located, which is threat for China's security. China wants to secure her sovereignty and national integrity, for that it focuses to improve the strategic and economic relations with Pakistan.

However, as discussed earlier, the world international trade route $\mathrm{KKH}$ is passing through the Gilgit Baltistan, which has a great importance for China because it maintains the position of superior military of China against India. For the centuries, the presence of $\mathrm{KKH}$ has increased the importance of the region where Pakistan lies as it is important trade route with the total length of $1300 \mathrm{~km}$ in which $887 \mathrm{~km}$ road passes through Pakistan while $423 \mathrm{~km}$ in China.

The construction of the road was initiated in 1959 and after 27 years of hard work, it was completed in 1986. This route not only connects important areas of both countries but also provides China's access to Arabian Sea. KKH can be considered as the most attractive symbol of Sino-Pak relationship by realizing the slogan 'relationship between China and Pakistan is higher than mountain'. For centuries, this route has been playing an important role in trade and investment. Presently, it leads to the energy and shipping corridor of Gwadar deep seaport, which connects the entire region including China with the Persian Gulf. In fact, China followed the 'String of Pearls', an aggressive mediating policy in order to build diplomatic relations 
with the South Asian counties including Pakistan and Bangladesh. The main objective of this mega project was to provide a safe sea trade route through Chittagong and Gwadar etc.

As Central Asian States and Afghanistan are landlocked states; however, Pakistan provides a route link between CARs, Afghanistan and Indian Ocean through $\mathrm{KKH}$ and Gwadar port. Most of the countries, which are trading with CARs, have to pass through this link route, which provides an easy access to international market. In addition to this, it enhances a great influence of China in the entire region of Arabian Sea. The strategic significance of the KKH for China is to connect Tibet and Xinjiang through the area of Aksai, which can be used for its military potential. Its length, bridges and geographical connection are enough to be used in the case of Indian aggression (Ali, 2001). By realizing these realities, China decided to help Pakistan to up-grade the infrastructure of $\mathrm{KKH}$.

It is a comprehensive package including the building of oil and gas pipeline, railways, links and up gradation of KKH. In fact, both states have been constructing the net of routes in Pakistan under the mega project known as CPEC. Equally, important aspect of this mega project is to construct the railways between China and Pakistan linking the region of Xinjiang region with Pakistan. The main aim of the developing railway line is to ensure transportation of energy resources by providing an alternative passage, in case of any aggression or climatic disorder. The project formally started with the signing ceremony in 2015, which extended Pak-China ties up to new heights. With the estimated cost of US \$ 46 billion, the CPEC was to provide a comprehensive package of communication, energy, health, education and industry. The construction of roads including $\mathrm{KKH}$ Phase II (Thakot to Havelian Section), Peshawar Karachi Motorway, Khuzdar-Basima Road N-30, Up gradation of D.I. Khan-Zhob N-50, KKH Thakot-Raikot N-35 and Gwadar East-Bay Expressway provided China a secure linkage to the Arabian Sea. 
Similarly, railway project includes expansion and reconstruction of existing ML-1, Havelian Dry Port (450 M. Twenty-foot Equivalent Units) and Capacity Development of Railways. Other than road track, the Siachen Glacier also has a geo-political implication for China; through the glacier, Pakistan has linked its security to China to undermine Indian designs. It is a natural hurdle and both China and Pakistan can generate influential military might against their common enemy. China is world's fastest emerging economy, which desires a massive energy reservoir to continue its status. For the trade of raw material and goods, China assisted Pakistan to build the Karakoram Highway enabling it to approach outer parts of the world including Middle East, Persian Gulf and Arabian Sea (Bukhari, 2014). China is not the part of South Asian countries but it has certain political, strategic and economic interests in this region.

By challenging Indian hegemony, both Pakistan and China keep strong strategic ties in all conditions. In current global environment, strategic policies of China toward South Asian states can be modified as both India and Pakistan are extremely vital for Chinese interest (Shahi, 2015). China's claims on Hunza valley have been resolved according to 1963 agreement. This region is now much vital for China for energy transport. However, Indo-China boundary dispute is still unresolved. Now China's very careful focus is on eastern part because western side of Aksai Chin is not as much important for China. By accessing Northern Areas, China might access towards Afghanistan where the allied forces are busy in reconstruction process. China also has its personal interests to attain its due share in these projects. Therefore, through AJK, access towards Afghanistan is very easy. Like other major powers of the World, China is increasing its influence beyond its borders through soft means (Bukhari, 2014).

As discussed earlier that Pakistan and China are enjoying very close and friendly relations since the establishment of diplomatic ties in May 1951. However, if these relationships have blossomed into an 'All weather strategic cooperation partnership' then the project of 
CPEC can be considered as its core. The level of their mutual interests placed these two countries very closer to each other where Pakistan considers China as its partner and China takes Pakistan as 'Iron Brother'. The leadership of both countries is committed to take this relationship forward as a state policy. A journey of 'Belt and Road', started by the then Prime Minister Nawaz Sharif for international cooperation, was taken on by the PTI government as well. In 2018, Prime Minister Imran Khan paid a historic visit to China where both sides agreed to strengthen the 'All Weather Strategic Cooperation Partnership'.

In the same year, China-Pakistan Free Trade Agreement was signed and CPEC project finally entered into its second phase. By realizing the importance of international trade, Prime Minister Imran Khan attended the First China International Import Expo (CIIE) in Shanghai. It was admitted that it is a leading initiative of China for opening its markets for the Pakistani products. In the meantime, another ground-breaking milestone in Pak-China friendship came in when Pakistan successfully launched Remote Sensing Satellite-1 (PRSS-1) from China's Jinquan Satellite Centre. This capacity enabled Pakistan to acquire the membership of Prestigious Space Club. In 2019, another milestone was achieved when Allama Iqbal Industrial City (M-3), Faisalabad Special Economic Zone finally materialized. In the meantime, Imran Khan's visit to attend the Second Belt and Road Forum for International Cooperation made Joint Working Group on International Coordination and Cooperation possible.

Pakistan, by playing its role equally important for China, hosted the third China-Afghanistan Pakistan Trilateral Foreign Ministers Dialogue in Islamabad to resolve the Afghan crisis and bring peace to the entire region. During his official visit to China in October 2019, Prime Minister Imran Khan established CPEC authority to coordinate and monitor the progress of the projects. In this regard, a CPEC Cell was established in the Pakistani Prime Minister's Office. Similarly, in the year of 2020, CPFTA-II became operational from 1st January due 
to which Pakistan may enjoy better access to the Chinese market. In fact, extensive bilateral coordination in the wake of the Corona virus pandemic, China is the major contributor who extended the largest amount of assistance to Pakistan in fighting the outbreak. These developments are playing an important role in further solidifying the historic bonds of trust and mutual support between the two 'timetested friends'.

\section{CONCLUSION}

After the successful launching of CPEC, established and time-tested friendship between Pakistan and China has converted into a strategic partnership for peace, security and development in the region. Very often, cooperation and understanding between China and Pakistan provides sensitivity to each other's vital national, political, and security interests. Leadership of both countries tries to maintain a strong relationship with each other to safeguard mutual interests. The fact is that Pak-China friendship has remained as one of the world's most enduring companionship. The strategic relationship between Pakistan and China can be understood from a universal strategic angle. The emerging economy of China is greatly dependent on the oil supply from the Persian Gulf. About 60 percent of the oil supply to China comes from the Gulf States. At first, this oil supply was through the Malacca Strait under influence of USA, but after moving to Shanghai, it must be shifted thousands of miles to the Western China. The Chinese leadership intended to use the geo-strategically significant location of Pakistan as a pipeline passageway to get gas and oil from the west Asian countries including Iran. Use of Karakoram Highway and Gwadar deep Seaport would be more appropriate in this regard.

In the present scenario, Gwadar port is the most significant aspect in Pakistan-China relationship. Taking the above facts the Chinese policy makers expedited the developmental process of CPEC as a vital part of Belt and Road policy. It is scholarly admitted that Belt 
and Road initiative as one of the largest infrastructure and investment projects in the history, covering more than 68 countries, including 65 per cent of the world's population and 40 per cent of the global gross domestic product as of 2017. For Pakistan, it will provide a major transportation point to connect Eurasian area with South Asia and for China; it is an alternate but secure means for importing energy at lesser cost and time.

In addition to this, the western province of China Xinjiang is a Muslim populated province, which is considered the sixth of the China's total territory. However, it is comparatively an underdeveloped area of China, for which China wants to stable this region and makes every effort to have friendly relations with its neighbouring countries. By realizing the importance of Pakistan, China decided to use the Pakistani platform to have friendly relationship with the Muslim World. During early 1980s, Pakistan decided to facilitate Chinese Muslims (Uighurs) to perform Haj and to get religious education in Pakistani Madrassa. Pakistan, the only nuclear power of Islamic world, helped repeatedly to establish good relation with the Muslim countries.

\section{REFERENCES}

Ali, G. (2013). China's strategic interests in Pakistan's port at Gwadar. Islamabad: Institute of Information Technology.

Alvi, M. (2016, October 2). President, prime minister felicitate Chinese counterparts. The News.

Ali, M. (2001). Readings in Pakistan foreign policy: 1971-1998. Karachi: Oxford University Press.

Bukhari, S. W. H. \& Parveen, T. (2014). China's Approach Towards Kashmir Conflict: A Viable Solution' Journal of Professional Research in Social Sciences, 1(1),14-15. 
Cheema, Z. (2015). Geostrategic importance of China-Pakistan Economic Corridor. Foreign Policy News. Retrieved from https://foreignpolicynews.org/2015/11/25/geostrategicimportance-of-china-pakistan-economic-corrido

Cohen, S. P. (2011). The future of Pakistan. Washington. D.C.: The Brookings Institution.

Durrani, S. Q., Bilal, M., \& Kalim, I. (2017). Pakistan-China Strategic Partnership: Capitalizing the geo-political location of Pakistan. Global Regional Review, 2(1), 152-165.

Dwivedi, S. S. (2011). Pakistan-China and North Korea-China: A Comparison. Indian Journal of Asian Affairs, 24(1/2), 63-75.

Ebinger, C. K. (2011). Energy and security in South Asia: Cooperation or conflict. Washington, D. C: Brookings Institution Press.

Fayaz, S. (2016). Kashmir dispute between Pakistan and India: The way out. The Dialogue, 11(1),65-82.

Jetly, R. (Ed.). (2009). Pakistan in regional and global politics. New Delhi: Rutledge.

Hussain. E. (2017). China-Pakistan Economic Corridor: Will it sustain itself? Fudan J. Hum. Soc. Sci. 10, 145-159.

Kreft, H. (n.d). The geopolitical importance of Pakistan: A country caught between the threat of 'Talibanization' and the return to democracy. Retrieved from https://www.files.ethz.ch /isn/47558/Pakistan.pdf

Kumar, A. (2006). China-Pakistan economic relations. IPCS Special Report, Retrieved from https://www.files.ethz.ch/ isn/95442/IPCS-Special-Report 30.pdf

Malik, H. Y. (2012). Strategic importance of Gwadar port. Journal of Political Studies, 19(2), 57-69. 
Masood, A. (2016, October 2). Lack of qualitative data and clarity is a stumbling block in exploiting true potential of the CPEC projects. The News.

Naseem, N. (2014). Geopolitical value of Gwadar for the region. A Research Journal of South Asian Studies, 29(2), 519-530.

Nilofar, M., Jiang, W. S., \& Ishtiaque, M. (2014). The growing economic ties between Pakistan and China and its impact on the economy of Pakistan. International Journal of Research in Humanities, Arts and Literature, 2(12), 49-54.

Riaz, J. K. (2014). Pakistan-China social and economic relations. A Research Journal of South Asian Studies, 29 (2), 395-410.

Rizvi, H. A. (1993). Pakistan and geostrategic environment: A study of foreign policy. Karachi: Oxford University Press.

Sattar, A. (2015). Pakistan's foreign policy 1947-2012: A concise history. Karachi: Oxford University Press.

Shahi, A. (2015). Lecture Series-2015. Retrieved from mofa.gov.pk /agha-shahi

Shelton-Strong, S. J. (2014). A question of time? Reflecting on the strengths and shortcomings of lesson observation and feedback at the British Council Hanoi. Retrieved from https://nottingham.academia.edu/ScottShelton/Papers.

Small, A. (2015). The China-Pakistan axis: Asia's new geopolitics. London: Oxford University Press.

Synnott, H. (2009). Transforming Pakistan: Ways out of instability. London: Routledge. 